\title{
Study of Child Sexually Abused Cases in Cairo Governorates in the Period from (2012) to (2016)
}

\author{
Manar abo-Seria, Asmaa AbdelRahman, Hanan Hamed mostafa1 and Hisham Abdl-Hamid Farag ${ }^{2}$ \\ ${ }^{1}$ Forensic Medicine and Clinical Toxicology Department, Faculty of Medicine, Ain-Shams University, Cairo, Egypt. \\ ${ }^{2}$ Forensic Medicine Authority, Ministry of Justice, Cairo, Egypt
}

\begin{abstract}
Introduction Child sexual abuse (CSA) is a serious violation of human well-being and of the law. It is, sadly, an international problem of great magnitude that can affect children of all ages, sexes, races and socioeconomic classes. CSA is outlawed nearly everywhere in the world, generally with severe criminal penalties, including, in some jurisdictions, life imprisonment or capital punishment

Aim of the study to examine the incidence, risk factors and pattern of sexual assault in children to provide grounds for effective preventive measures and to heighten awareness of the health professionals.

Methods This is both retrospective and prospective study evaluating sexual assault against children that were referred to Medico-legal Office and violence against women and children clinic in the Medico-legal department of Ministry of Justice, Cairo, Egypt from 2012 to 2016.

Results The total number of CSA cases was 740 in the age range from 1 to18 years, females 391 (52.8\%) were more predominant than males 349 (47.2\%). The age group from 11 to 18 years accounted for the highest rate (56\%), mostly in females (62.6\%). El-Salaam was the most common district of reporting cases of child sexual abuse (9.7\%). Most CSA cases were committed by single perpetrator (87 \%) and most perpetrators were non-relative (89.1\%).The most frequently reported type of child sexual abuse was anal assault (55\%). Physical violence (27.7\%) was the most common threat used against child cases. Majority of cases were examined after the sexual assault by more than one week (40.4\%). Ecchymosis (6.1\%) was the most frequent wound seen upon examination of CSA cases. Head and neck were the most common site of traumatic lesions (5.1\%).

Conclusions Family doctors and other health professionals should be minded with suspecting signs of CSA and its short and long-term deleterious consequences to refer them to specialized authorities to overcome the delay of reporting and loss of forensic evidence.
\end{abstract}

\section{Introduction}

7 hildhood is considered a developmenal period with high vulnerability to physical and psychosocial risks. Child sexual abuse is one of the most stressful life events and is the outcome of a set of interrelated familial, social, psychological, and economic factors. CSA is associated with many adverse consequences, including physical and mental health problems, substance abuse, and criminality (Wahab et al., 2013).

CSA occurs when a child engaged in sexual activity for which he cannot give consent and cannot comprehend (Al-Eissa and Al-Muneef, 2010). Children may be sexually abused by family members as fathers, uncles and cousins or non-family member as friends of the family, neighbors and strangers (Pereda et al, 2009). Sexual activities may include all forms of oral-genital, genital, or anal contact, or child abuse that does not involve contact such as exhibitionism, voyeurism, or using the child in the production of pornography (RAINN, 2016).

Sexual assault is rarely reported for many reasons: social stigma, embarrassment, guilt, lack of awareness regarding victim's rights, unwillingness to confront the legal system. This underreporting makes determination of actual incidence a difficult and challenging task (Arif et al., 2014).

CSA is outlawed nearly everywhere in the world, generally with severe criminal penalties including life imprisonment or capital punishment (Hagras et al., 2011). In Egypt, there is no accurate Egyptian epidemiologic study assessing the extent of the problem of child sexual abuse. The first step in treatment and prevention of any problem should be started with determination of the extent of the problem and its 
characteristics which require collection of reliable data about it (El-Gendy et al., 2013).

\section{Subjects and method}

This is both retrospective and prospective study evaluating sexual assault against children in Cairo governorate in Egypt from 2012 to 2016 The files of all cases of CSA referred to Medico-legal Office and violence against women and children clinic in the Medico-legal department of Ministry of Justice, Cairo during the study period from January 2012 to October 2016 were investigated to fulfill the following: demographic data (age, sex and referring authority ), number of perpetrators, relation between the victims and perpetrators, type of CSA, type of threat used against victims, general examination including evidence of general violence, local examination of genitalia and anus and time lapse between last assault and medico-legal examination.

An official permission for perusal of records and appropriate data retrieval was obtained from the head of Egyptian forensic medicine authority. The Local Research Ethics Committee approval was also obtained. All personal data were kept anonymous to ensure confidentiality of records.

The collected data were analyzed using the Statistical Package for the Social Sciences version 23 (Statistical Package for the Social Sciences Inc, Chicago, IIl). The collected data were statistically presented and analyzed using Chi-square test to test the significance between different variables at $\mathrm{P}<0.05$.

\section{Result}

A total of 740 cases were referred to Medico-legal Office and violence against women and children clinic during the period of the study. Females were predominated than males as a victims of CSA (52.8\%\% versus $47.2 \%)$ as shown in figure (1).

The age group (11-18 years) (56\%) represented the greatest proportion of cases of CSA followed by age group from 5-10 years (39\%) while the age group (1-4 years) (5\%) were the least frequent age group as shown in figure (2).

Female victims were the most predominant in age group (1-4 years) (64.9\%) and age group (11-18 years) $(62.6 \%)$, while male victims were predominant in age group (5-10 years) (62.6\%) as shown in table(1)

El-Salaam was the most common authority of reporting cases of CSA and the least common authority was Bolak-Dakror as shown in table (2).
Non- relative perpetrators (89.1\%) were more predominant than relative perpetrators (10.9\%).From non-relative perpetrators, the most frequent perpetrators were strangers (34.9\%) followed by boyfriends (28.1\%). From relative perpetrators, relative to family (2.6\%) were more predominant than both uncle and father $(2.3 \%$ each). The least frequent perpetrators were grandfather and sister (0.1\%each) as shown in table (3).

The most frequent used threat against child cases was physical violence (27.7\%) followed by armed threat $(21.9 \%)$.The least frequent used force was drug facilitated (3.5\%) as shown in table (4).

The majority of child abused cases were examined after the sexual assault by more than one week (40.4\%). Child cases that were examined within first three days after the assault (34.1\%) showed higher percentage than those examined after three days up to one week (25.5\%) as shown in figure (3). Majority of child sexually abused cases were committed by one perpetrator (87\%) as shown in figure (4).

The majority of child cases (87.7\%) showed no traumatic lesion in their body during external examination. Ecchymosis (6.1\%) was the most frequent wound in CSA cases, followed by abrasions (3.8\%). Other type of lesions (0.5\%) such as firearm, stab wound and burn were the least frequent wound among examined cases as shown in table (5).

Head and neck (5.1\%) were the most common site of traumatic lesions, followed by thigh (4.1\%). The back $(0.8 \%)$ of the child cases was the least common site that was affected during the sexual assault as shown in table (6).

The most frequently reported type of child sexual abuse in that study was anal assault (55\%) followed by vaginal penetration (33.5\%), while the least frequent type was both vaginal and anal penetration (11.5\%) as shown in table (7).

Anal assault was more predominant in males (86\%) than females (14\%) as shown in figure (5).

Most of child sexually abused cases presented with no anogential finding during medico-legal examination that $71.6 \%$ female cases presented with intact hymen without traumatic lesion and $87.1 \%$ of all cases examined presented with no anal injuries. Female victims that presented with recent traumatic lesion without penetration of hymen (2.6\%) were the least among the examined cases as shown in table (8). 
Table (1): Statistical analysis Chi-square test $\left(x^{2}\right)$ to compare the distribution of gender in relation to age groups of child sexually abused cases that were examined in Medico-legal authorities in Cairo during the period from 2012 to 2016.

\begin{tabular}{|c|c|c|c|c|c|c|c|}
\hline \multirow{3}{*}{ Gender of child } & \multicolumn{6}{|c|}{ Age group of child } & \multirow{3}{*}{$\begin{array}{c}\text { Test value } \\
\text { P-value } \\
\text { Sig. }\end{array}$} \\
\hline & \multicolumn{2}{|c|}{ Age 1-4 years } & \multicolumn{2}{|c|}{ Age 5-10 years } & \multicolumn{2}{|c|}{ Age 11-18 years } & \\
\hline & Number & $\%$ & Number & $\%$ & Number & $\%$ & \\
\hline Female & 24 & $64.9 \%$ & 108 & $37.4 \%$ & 259 & $62.6 \%$ & \multirow{3}{*}{$\begin{array}{c}x^{2}=45.598 \\
\text { P-value }=0.000 \\
\text { HS }\end{array}$} \\
\hline Male & 13 & $35.1 \%$ & 181 & $62.6 \%$ & 155 & $37.4 \%$ & \\
\hline Total & 37 & $100 \%$ & 289 & $100 \%$ & 414 & $100 \%$ & \\
\hline
\end{tabular}

Table (2): Distribution of child sexually abused cases in different geographic areas in Cairo that were referred to Medico-legal authorities in Cairo during the period from 2012 to 2016

\begin{tabular}{|l|c|c|l|c|c|}
\hline Authority & Number & $\mathbf{\%}$ & Authority & Number & $\%$ \\
\hline Abdeen & 11 & $1.5 \%$ & Marg & 45 & $6.1 \%$ \\
\hline Ain- Shams and Mataria & 47 & $6.4 \%$ & Masr- Kadeema & 24 & $3.2 \%$ \\
\hline Amirya & 17 & $2.3 \%$ & Mosky & 8 & $1.1 \%$ \\
\hline Bab- Shaereyia and El- Daher & 10 & $1.4 \%$ & New- Cairo & 32 & $4.3 \%$ \\
\hline Basateen & 43 & $5.8 \%$ & Nozha & 14 & $1.9 \%$ \\
\hline Bolak- Dakror & 4 & $0.5 \%$ & Zawya- Hamra and Waily & 12 & $1.6 \%$ \\
\hline Child & 58 & $7.8 \%$ & Sayda- Zienab & 42 & $5.7 \%$ \\
\hline Gamalya & 11 & $1.5 \%$ & EL- Salaam & 72 & $9.7 \%$ \\
\hline Hadaek El -Koba & 25 & $3.4 \%$ & Sharabya & 17 & $2.3 \%$ \\
\hline Helwan & 50 & $6.8 \%$ & Shark & 5 & $0.7 \%$ \\
\hline Kalifa and Mokatam & 27 & $3.6 \%$ & Shoubra & 39 & $5.3 \%$ \\
\hline Maadi & 10 & $1.4 \%$ & El-Tabeen and 15 Mayo & 10 & $1.4 \%$ \\
\hline Madinat- Nasr & 46 & $6.2 \%$ & Wasat & 27 & $2.3 \%$ \\
\hline Manshiat -Nasr & 17 & $2.3 \%$ & Others & $3.6 \%$ \\
\hline
\end{tabular}

Table (3): Relationship between perpetrators and child sexually abused cases that were examined in Medico-legal authorities in Cairo during the period from 2012 to 2016.

\begin{tabular}{|c|c|c|c|c|c|}
\hline \multicolumn{6}{|c|}{ Relationship between perpetrators and child cases } \\
\hline \multicolumn{3}{|c|}{ Non relative $659(89.1 \%)$} & \multirow[t]{2}{*}{ Relative } & \multicolumn{2}{|l|}{$81(10.9 \%)$} \\
\hline & Number & $\%$ & & Number & $\%$ \\
\hline Stranger & 258 & $34.9 \%$ & Relative to family & 19 & $2.6 \%$ \\
\hline Boy friend & 208 & $28.1 \%$ & Father & 17 & $2.3 \%$ \\
\hline Neighbor & 164 & $22.2 \%$ & Uncle & 17 & $2.3 \%$ \\
\hline Worker & 6 & $0.8 \%$ & Cousin & 12 & $1.6 \%$ \\
\hline Bus driver & 6 & $0.8 \%$ & Step-father & 9 & $1.2 \%$ \\
\hline Teacher & 17 & $2.3 \%$ & Brother & 5 & $0.7 \%$ \\
\hline & & & Grandfather & 1 & $0.1 \%$ \\
\hline & & & Sister & 1 & $0.1 \%$ \\
\hline
\end{tabular}


Table (4): The threat used against child sexually abused cases that were examined in Medico-legal authorities in Cairo during the period from 2012 to 2016.

\begin{tabular}{|l|l|l|}
\hline $\begin{array}{l}\text { The threat used against } \\
\text { child cases }\end{array}$ & Number & \% \\
\hline Physical & 205 & $27.7 \%$ \\
\hline Armed & 162 & $21.9 \%$ \\
\hline Verbal & 121 & $16.4 \%$ \\
\hline No information & 98 & $13.2 \%$ \\
\hline Without threat & 128 & $17.3 \%$ \\
\hline Drug facilitated & 26 & $3.5 \%$ \\
\hline Total & 740 & $100 \%$ \\
\hline
\end{tabular}

Table (5): Distribution of the traumatic lesions in whole body (except gentiala) during external examination of child cases that were referred to Medico-legal authorities in Cairo during the period from 2012 to 2016.

\begin{tabular}{|l|l|l|}
\hline $\begin{array}{l}\text { Type of traumatic lesion during } \\
\text { external examination }\end{array}$ & Number & \% \\
\hline No & 649 & $87.7 \%$ \\
\hline Ecchymosis & 45 & $6.1 \%$ \\
\hline Abrasion & 28 & $3.8 \%$ \\
\hline Ecchymosis and abrasion & 9 & $1.2 \%$ \\
\hline Cut wound & 5 & $0.7 \%$ \\
\hline Other ( firearm, stab wound and burn) & 4 & $0.5 \%$ \\
\hline Total & 740 & $100.0 \%$ \\
\hline
\end{tabular}

Table (6): Distribution of the site of traumatic lesions in whole body (except gentiala) during external examination of child cases that were referred to Medico-legal authorities in Cairo during the period from 2012 to 2016.

\begin{tabular}{|c|c|c|c|}
\hline \multirow{2}{*}{$\begin{array}{c}\text { Site of traumatic } \\
\text { lesion }\end{array}$} & Number & \% \\
\hline \multirow{2}{*}{ Arm } & Negative & 718 & $97.0 \%$ \\
\cline { 2 - 4 } & Positive & 22 & $3.0 \%$ \\
\hline \multirow{2}{*}{ Wrist } & Negative & 731 & $98.8 \%$ \\
\cline { 2 - 4 } & Positive & 9 & $1.2 \%$ \\
\hline \multirow{2}{*}{ Buttock } & Negative & 722 & $97.6 \%$ \\
\cline { 2 - 4 } & Positive & 18 & $2.4 \%$ \\
\hline \multirow{2}{*}{$\begin{array}{c}\text { Head } \\
\text { and } \\
\text { neck }\end{array}$} & Negative & 702 & $94.9 \%$ \\
\cline { 2 - 4 } Breast & Positive & 38 & $5.1 \%$ \\
\cline { 2 - 4 } & Negative & 731 & $98.8 \%$ \\
\hline \multirow{2}{*}{ Thigh } & Positive & 9 & $1.2 \%$ \\
\cline { 2 - 4 } & Pogative & 710 & $95.9 \%$ \\
\hline \multirow{2}{*}{ Back } & Negative & 734 & $9.1 \%$ \\
\cline { 2 - 4 } & Positive & 6 & $0.8 \%$ \\
\hline
\end{tabular}

Table (7): Distribution of the types of sexual abuse in child cases that were examined by Medico-legal authorities in Cairo during the period from 2012 to 2016.

\begin{tabular}{|l|l|l|}
\hline $\begin{array}{l}\text { Types of sexual child abuse } \\
\text { (based on victim information ) }\end{array}$ & Number & \% \\
\hline Anal assault & 407 & $55 \%$ \\
\hline Vaginal penetration & 248 & $33.5 \%$ \\
\hline Both & 85 & $11.5 \%$ \\
\hline Total & 740 & $100 \%$ \\
\hline
\end{tabular}


Table (8): Anogential finding (hymenal and anal finding) during examination of child sexually abused cases in Medico-legal authorities in Cairo during the period from 2012 to 2016.

\begin{tabular}{|l|l|l|l|}
\hline \multicolumn{1}{|l|}{ Anogential Finding } & \multicolumn{1}{|l|}{ Number } & $\%$ \\
\hline \multirow{4}{*}{ HYMENAL FINDING } & Intact hymen without traumatic lesion & 247 & $71.6 \%$ \\
\cline { 2 - 5 } & Old penetration of hymen & 70 & $20.3 \%$ \\
\cline { 2 - 5 } & Recent penetration of hymen & 19 & $5.5 \%$ \\
\cline { 2 - 5 } & Recent traumatic lesion without penetration of hymen & 9 & $2.6 \%$ \\
\cline { 2 - 5 } & Total & 345 & $100 \%$ \\
\hline & No anal finding & 466 & $87.1 \%$ \\
\cline { 2 - 4 } & Recent penetration of anus & 50 & $9.3 \%$ \\
\cline { 2 - 4 } & Chronic sodomy sign & 19 & $3.6 \%$ \\
\cline { 2 - 4 } & Total & 535 & $100 \%$ \\
\hline
\end{tabular}

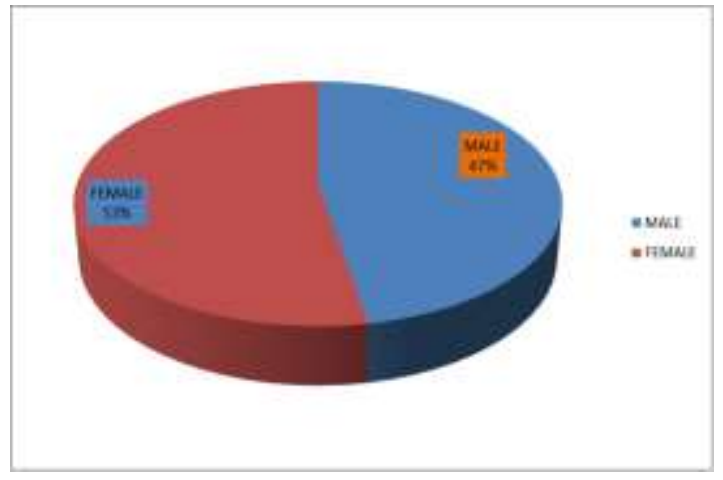

Figure (1): Gender distribution of cases of sexual child abuse that were examined by Medico-legal authorities in Cairo during the period from 2012 to 2016.

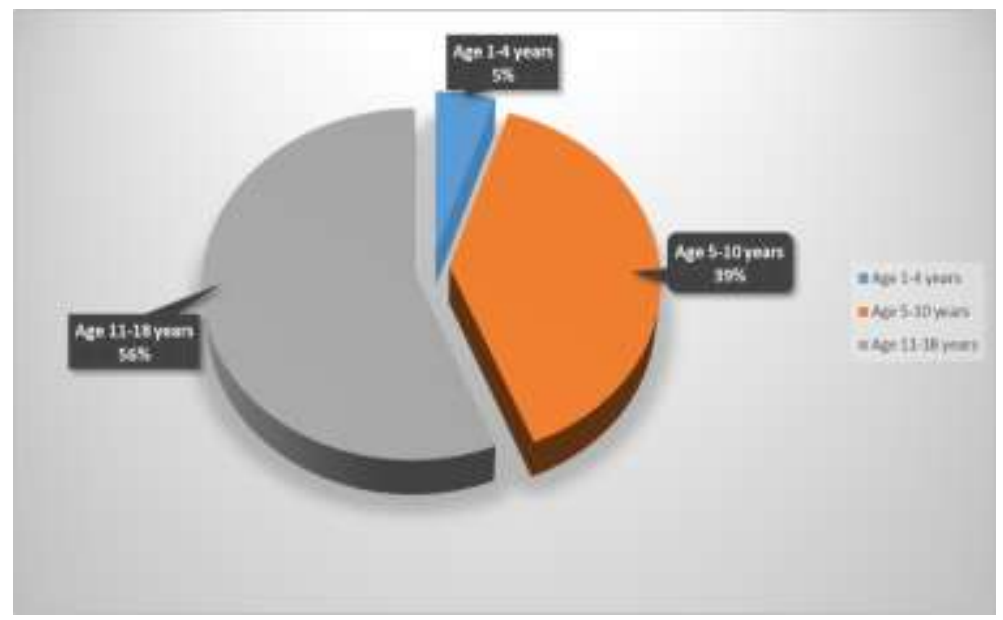

Figure (2): Distribution of age groups of the cases of sexual child abused cases that were examined by Medico-legal authorities in Cairo during the period from 2012 to 2016. 


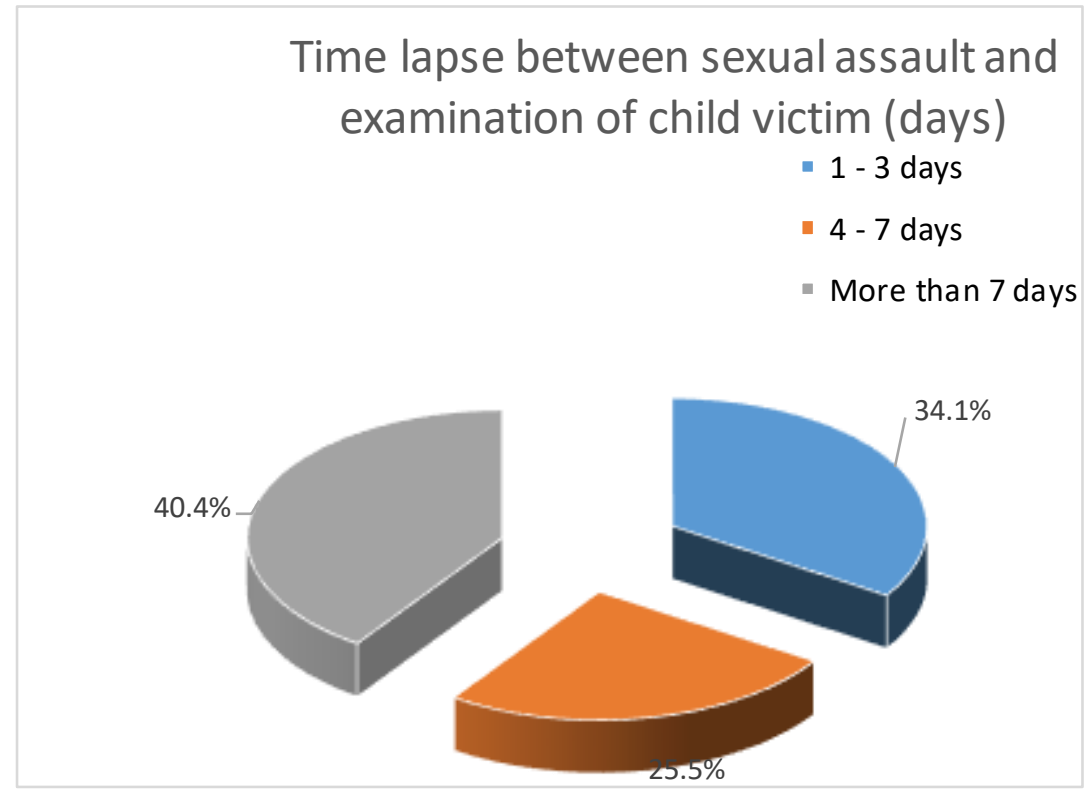

Figure (3): Time lapse between sexual child abuse and the examination by the Medico-legal authorities in Cairo during the period from 2012 to 2016
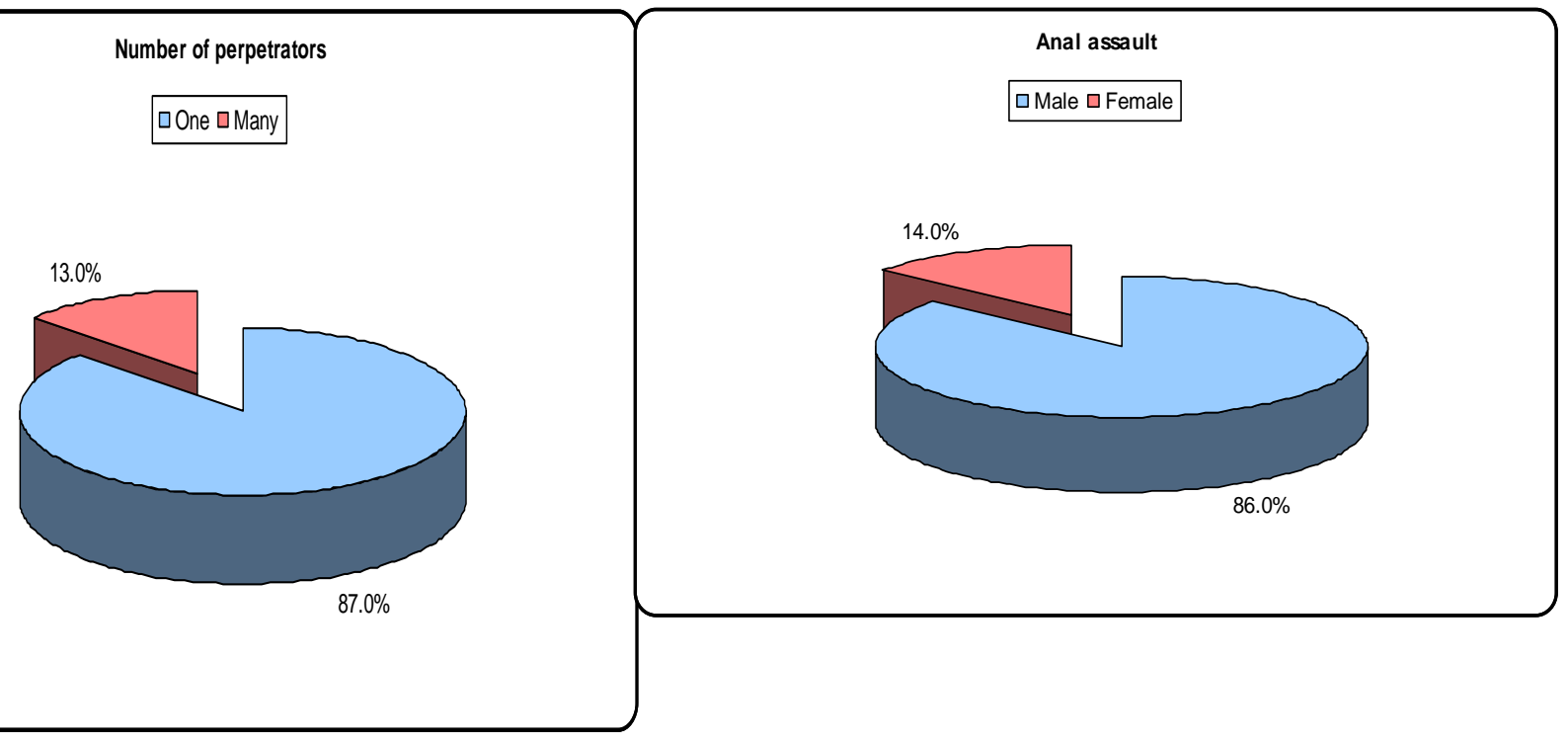

Figure (4): Distribution of the number of perpetrators that committed sexual abuse to child cases that were referred Medico-legal authorities in Cairo during the period from 2012 to 2016.

\section{Discussion}

Sex crimes are complex and multidimensional over the past few decades, child sexual abuse has gained public attention and become one of the most high-profile crimes. CSA is considered one of the greatest threats to a child's well-being, and safety prevention and dealing with this situation is no easy task (Waheb et al., 2016).
Figure (5): Percentage of anal assault in relation to the gender of child sexual cases that were examined in Medicolegal authorities in Cairo during the period from 2012 to 2016.

In the present study, the total number of CSA cases were 740 . This agrees with another study conducted In the Dakahlia Governorate where 650 cases of sexual offenses were reported in the period from 1996 to 2000 (Maklad et al., 2009).However, this number is small compared to other studies done in Shanghai where 
1,099 cases experienced CSA in 2009 (NIU et al., 2010).This disparity between this study and that was done in Shanghai may be due to underreporting makes which determination of actual numbers of incidence a difficult task (Metwaly et al., 2013).

In the present study, females (52.8\%) were more predominant than males (47.2\%) in CSA cases. This is in accordance with study done by Aboul-Hagag et al. (2012) and Sohail et al. (2014) who concluded that females are predominant than males in child sexual assault. The reason for this is that attention from parents, teachers, pediatricians, and other childcare professionals regarding CSA was primarily paid to girls. Boys seem to resist disclosure of sexual abuse because of fear of punishment, stigma against homosexuality and loss of self-esteem (Maikovich-Fong et al., 2010). The present results are in contrast to the results of Magalhaes et al. (2009) who reported that number of male victims is greater in childhood.

The study showed that age groups (11-18 years) (56\%) represented the greatest proportion of cases of CSA followed by age group (5-10 years) (39\%) while the age group (1-4 years) (5\%) were the least frequent age group exposed to sexual abuse among the included cases. This agrees with Hassan et al. (2007) and Arif et al. (2014) who revealed that the highest incidence of child sexual assault was found in age group (11-18years). However, Al-Mahroos and Al-Amer (2011) and AlMadani et al. (2012) reported that the majority of CSA cases were in primary school or age group (6 - 12 years) while the least frequent of CSA was reported in age group (11-18 years).

The study showed that El-Salaam was the most common district of reporting cases of child sexual abuse (9.7\%).The least common authority was BolakDakror (0.5\%). El-Gendy et al. (2013) found that Matarya and Bolak-Dakror which had the lowest socioeconomic status categories, had the highest number of victims. Moqutam, which had a high social class, had the lowest number of victims. Also, El-Sayed et al. (2017) found that Ain-Shams and Mataria were the most common regions in Cairo referring cases of child abuse, Kasr El-Nile had the lowest number of sexually abused victims.

The current study showed that the nonrelative perpetrators (89\%) were more predominant than relative perpetrators (11\%). From non-relative perpetrators, the most frequent perpetrators were strangers (34.9\%) followed by boyfriends (28.1\%). From relative perpetrators, relative to family $(2.6 \%)$ were more predominant than both uncle and father (2.3\% each). The least frequent perpetrators were grandfather and sister (0.1\%each). This agrees with previous studies which conducted by Sharaf El-Din et al. (2015) and Shetty et al. (2017) who showed that extra-familial perpetrators were more predominant than intra-familial perpetrators. However, Olsson et al. (2008) and Saint-Martin et al.
(2014) reported that sexual abuse by intra-familial offenders were more common than that by extra-familial.

The present study showed that the most frequent used threat was physical violence (27.7\%) followed by armed threat (21.9\%).The least frequent used force was drug facilitated (3.5\%). This agrees with previous study conducted by Suri and Sanjeeda (2013) and Patra et al. (2015) who reported that majority of child cases alleged that, the accused person physically forced or coerced them for sexual intercourse. This is in contrast to studies done by Okonkwo and Libel (2002) and Shetty et al. (2017) who observed that most of child victims were under the influence of alcohol or drugs at the time of assault.

In the present study, the majority of child abuse cases were examined after the sexual assault by more than one week (40.4\%).Child cases that were examined within first three days after the assault (34.1\%) showed higher percentage than those examined after three days up to one week (25.5\%). This agrees with previous studies conducted by Al-Madani et al. (2012) and Patra et al. (2015) who reported that majority of child cases were examined after the alleged assault by more than one week. In contrast to the current results, Sohail et al. (2014) and Ali et al. (2015) reported that majority of child victims were examined within first $72 \mathrm{hrs}$ of the alleged assault. The time of reporting for medico-legal examination after the sexual assault is very important whereas the likelihood of documentation of injuries and collecting evidentiary material decreases with the passing of time interval between the assault and medical examination (Maqsood et al., 2014).

In the present study, majority of child sexual abuse cases were committed by one perpetrator (87\%) while $13 \%$ of cases were committed by more than one perpetrator. This agrees with Metwaly et al., (2013) and Küçüker (2008) who revealed that, most of child sexually abused cases were committed by one perpetrator. In contrast to the current results, Manzoor et al. (2010) and Arif et al. (2014) observed that, majority of child sexual abuse cases were committed by more than one perpetrator.

The present study showed that the majority of child cases $(87.7 \%)$ showed no traumatic lesion in their body during external examination. Ecchymosis (6.1\%) was the most frequent wound in CSA cases. These results are in agreement with previous studies of Saint-Martin et al. (2014) and Waheb (2016) who reported that the medico-legal examination did not reveal traumatic injuries in whole body except gentiala. Bruises represented the most common type of injury. In contrast to the present study, general body trauma was more predominant in the series by White and McLean (2006) and Kucuker (2008).

This study showed that the most frequently reported type of child sexual abuse was anal assault (55\%).These results are in agreement with previous studies conducted by Metwaly et al. (2013) and El- 
Gendy et al. (2013) in different governorates in Egypt as Quena and Greater Cairo. In contrast to the present results, Sarker et al. (2005) and Maqsood et al. (2014) reported that the most frequent type of child sexual assault was vaginal penetration.

In the present study, most of child sexually abused cases presented with no anogential finding during medico-legal examination that $71.6 \%$ female cases presented with intact hymen without traumatic lesion and $87.1 \%$ of all cases examined presented with no anal injuries. Female victims that presented with recent traumatic lesion without penetration of hymen (2.6\%) were the least among the examined cases. This agrees with Al-Madani et al. (2012) and El-Gendy et al. (2013) who found that most of child sexually abused cases showed intact hymen. Also, there is a similarity between this current results and a study conducted by EL-Sayed et al. (2017) who mentioned that anal injuries were evident in $15 \%$ of child victims. This is in contrast with previous studies conducted by Pal et al. (2015) and Kaushik et al. (2016) who found that cases with old hymenal tear were more than those with intact hymen.

\section{Conclusions and recommendations}

Social awareness, sensitization and protection programs should be focused on CSA to increase awareness of the child, family and society and how to respond to such situation. Strengthening and expanding laws defining sexual assault especially CSA should proceed with improving the application of existing laws.

\section{References}

Aboul-Hagag KE, Hilal MA and Mohamed SA, (2012): Prevalence and pattern of child sexual abuse reported by cross sectional study among the University students, Sohag University, Egypt. Egyptian journal of forensic sciences, 10(1):264-274.

Al-Eissa M and Al-Muneef M, (2010): Child abuse and neglect in Saudi Arabia: journey of recognition to implementation of national prevention strategies. Child Abuse and neglect, 34(1): 2833.

Ali N, Akhter S, Nur Hossain N and Khan NT, (2015): Rape in Rural Bangladesh. Delta Med Col J; 3(1); 31-35.

Al-Madani O, Bamousa M, Alsaif D, Kharoshah MAA and Alsowayigh K, (2012): Child physical and sexual abuse in Dammam, Saudi Arabia: A descriptive case-series analysis study. Egyptian Journal of Forensic Sciences, 33-37.

Al-Mahroos F and Al-Amer E, (2011): Reported child sexual abuse in Bahrain: 2000-2009. Annals of Saudi medicine, 16(8): 455-459.

Arif M, Ahmed M and Chaudhary KM, (2014): Medicolegal analysis of child and adolescent victims of sexual assault in Lahore- A Retrospective study. Professional Med J; 8(2):980-986.

El-Gendy IS and Hassan NA, (2013): Medico-legal study of child sexual abuse in greater Cairo,
Egypt, during a 7-year period: 2005-2011. Am

J Forensic Med Pathol, 34: 335-341

El-Sayed MR, Azab SM and El-Sayed A, (2017): Study of child abuse cases in Cairo and Giza governorates in the period from 2007 to 2011.Forensic medicine, Ain Shams University, Thesis. Journal of child sexual abuse, 26(3):308-318.

Hagras AM, Moustafa SM, Barakat HN, Azza H and ElElemi AH, (2011): Medico-Legal evaluation of child sexual abuse over a six-year period from 2004 to 2009 in the Suez Canal area, Egypt. Egypt J Forensic Sci, (1):58-66.

Hassan Q, Bashir MZ, Mujahid M, Munawar AZ, Aslam M and Marri MZ, (2007): Medico-legal assessment of sexual assault victims in Lahoure. J Pak Med Assoc, 57(11): 539-542.

Kaushik N, Pal KS, Sharma A and Thakur CG, (2016): A Retrospective Study of Sexual Assaults in Southern Range of Himachal Pradesh International Journal of Health Sciences and Research. Available at: www.ijhsr.org ISSN: 2249-957.

Küçüker H, (2008): Analysis of 268 child and adolescent victims of sexual assault and the legal outcome. Turkish Journal of Pediatric, 50: 313-316.

Magalhaes T, Taveira F, Jardim P, Santos L, Matos E and Santos A, (2009): Sexual abuse of children. A comparative study of intra and extra-familial cases. J Forensic Legal Med, 16(8): 455-459.

Maikovich-Fong AK and Jaffee SR, (2010): Sex differences in childhood sexual abuse characteristics and victim's emotional and behavioral problems: Findings from a national sample of youth. Child Abuse Negl, 34: 429437.

Maklad AI, El-Mehy IM and El-Shazly M, (2009): A medico-legal study of sexual offences in Dakahlia Governorate. Zagazig J Forensic Med Toxicol, 4(1): 75-94.

Manzoor I, Hashmi NR and Mukhtar F, (2010): Medico-legal Aspects of Alleged Rape Victims in Lahore. J. Coll.Physicians Surg. Pak, 20(12): 785-789.

Maqsood M, Arif M and Butt KM, (2014): Incidence of Alleged Sexual Assault Cases in Lahore: It's Medico-legal and Social Aspects. Professional Med J, 8 (1):50-55.

Metwaly M, Ismail AM, Sherif MM, Mahmoud FS, Mohammed NI and Assasa FM, (2013): Study about sexual offences in Quena governorates. J Forensic Res, 19, 2.

NIU H, Lou C, Gao E, Zuo X and Feng Y, (2010): Analysis of childhood sexual abuse among 1099 university, students in Shanghai. J Reprod Contracept, 21(1): 53-61. 
Okonkwo JEN and Libel C, (2002): Female sexual assault in Nigeria. International Journal of Gynecology and obstetrics, 83(3):326-325.

Olsson A, Ellsberg E, Berglund S, Herrera A, Zlaya E , Pena R, et al., (2008): Sexual abuse during childhood and adolescence among Nicaraguan men and women: a population based anonymous survey. Child Abuse Negl, 24:1579-1589.

Pal SK, Sharma A, Sehgal A and Rana A, (2015): A study of sexual assault in northern range of Himachal Pradesh. Int J Med Toxicol Forensic Med; 5(2):64-72.

Patra PA, Shaha KK, Rayamane PA and Mohanty S, (2015): Victimology of alleged rape cases: A three year institution based cross- sectional study Indian Journal of Forensic and Community Medicine, 2(4): 203-213.

Pereda N, Guilera G, Forns M and Gómez-Benito J, (2009): The prevalence of child sexual abuse in community and student samples: A metaanalysis. Clinical Psychology Review, 29 (4):328-338

Rape, Abuse and Incest National Network (RAINN), (2016).

Saint-Martin P, Bouyssy M and O'Byrne P, (2014): Analysis of 756 cases of sexual assault in Tours (France): medico-legal findings and judicial outcomes. J Gynecol Obstet Biol Reprod (Paris), 36(6): 588-94.[Article in French]

Sarkar SC, Lalwani S, Rautji R, Bhardwaj DN and Dogra TD, (2005): A Study on Victims of Sexual Offences in South Delhi, Journal Famwelf, 51(1):60-6.

Sharaf El-Din AI, Elkholy MS, Eslam S and Farag HA, (2015): Pattern of Female Sexual Assault in Qalyubia Governorate, Egypt, During the
Period from 2009 to 2013: A Retrospective Study. The American Journal of Forensic Medicine and Pathology, 36 (4):276-284. doi:10.1097/PAF.0000000000000182.CME Articles.

Shetty KC, Biradar G and Shetty P, (2017): Sexual Assault in Ballari, Karnataka, India: A Four Year Retrospective Review. Arab Journal of Forensic Sciences \& Forensic Medicine, 7(2):35-40 doi:10.26735/16586794.2017.006.

Sohail K, Parveen M, Nadeem S and Aslam M, (2014): Female victims of sexualviolence; reported cases of in Faisalabad city in 2008. Professional Med, 17(4): 735-740.

Suri S and Sanjeeda (2013): An analytical study of rape in Delhi. International Journal of Education and Psychosocial Research, 2(3): 60-68.

Wahab S, Mooi -Koon ST, Marimuthu S, Razali R and Muhamad N, (2013): Young female survivors of sexual abuse in Malaysia and depression: What factors are associated with better outcome? Asia-Pacific Psychiatry, 5, 95-102. doi:10.1111/appy.12051.

Waheb MA, (2016): Child Sexual Abuse in Fayoum Governorate, Egypt (2010-2014). J Forensic Res, 7: 332. doi:10.4172/2157-7145.1000332.

White C and McLean I, (2006): Adolescent complainants of sexual assault; injury pattern in virgin and non- virgin groups. J Clin Forensic Med, 13(4): 172-180. 


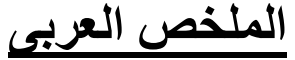

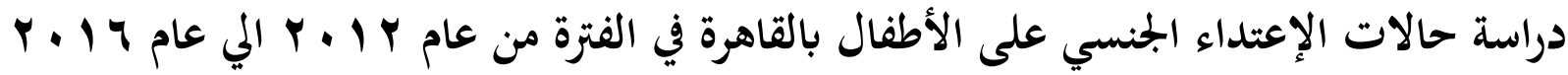

\section{منار ابوسريع فهمي و أسماء عبدالرحمن عبدالرحمن و حنان حامد مصطفي' و هشام عبدالحميد فرج؟}

مقدمة: إن الاعتداء الجنسي على الأطفال انتهاك خطير للإنسانية والقوانين كما اهما قضية عالمية ذات خطورة كبيرة جدا حيث انما

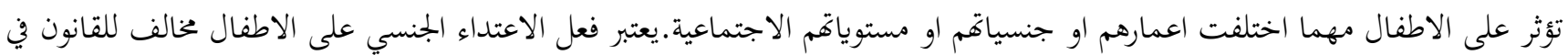
دول العالم وهذا الفعل جناية لما عقوبة شديدة تصل للحبس المؤبد واحيانا تصل للإعدام

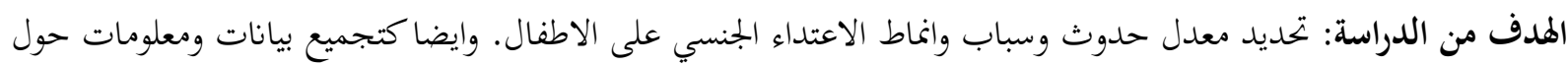

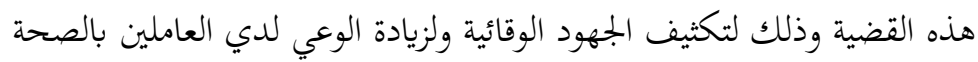

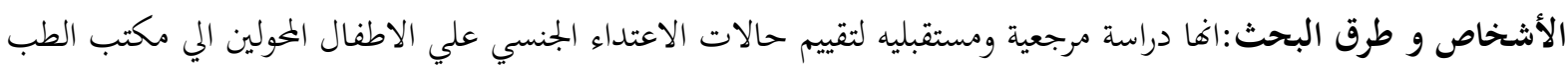

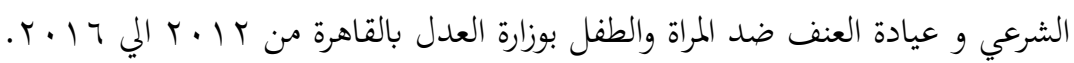

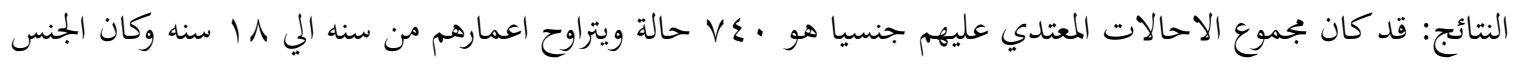

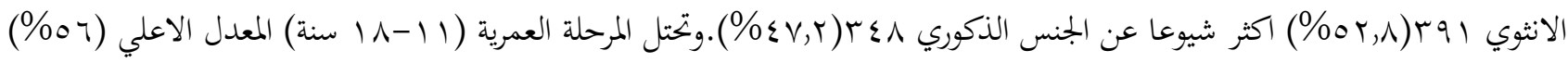

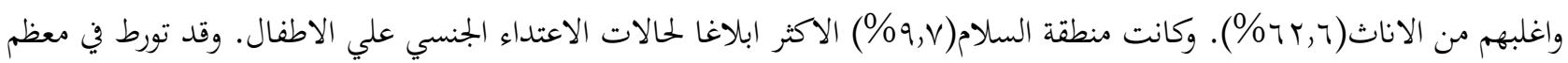

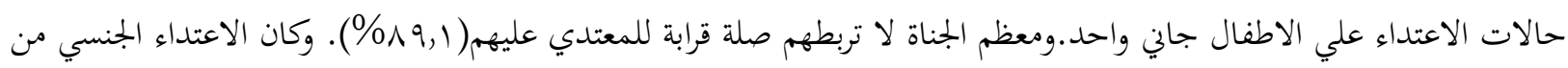

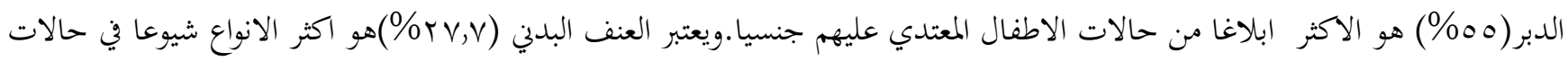

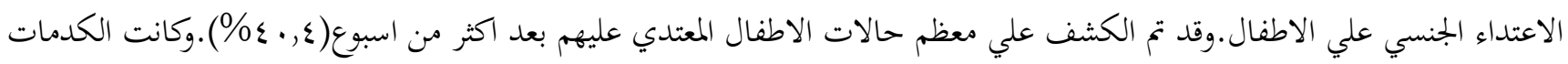

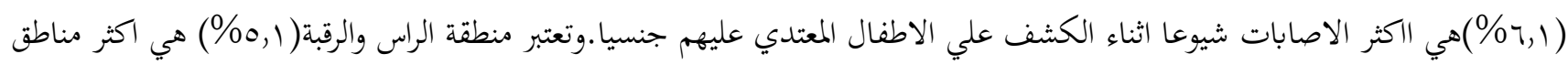
الجسم تاثيرا بالاصابات.

الاستنتاجات و التوصيات:يجب علي الاطباء الاسرة والعاملين بالصحة ادراك الاعراض المشيرة علي الاعتداء الجنسي علي الاطفال

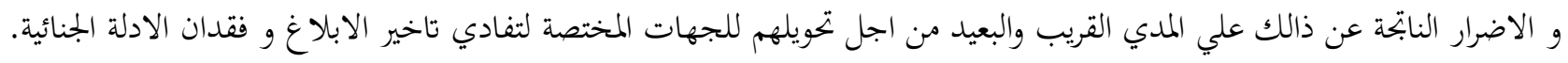

